\title{
HAMPIRAN SOLUSI PERSAMAAN PANAS DIMENSI SATU DENGAN METODE BEDA HINGGA CRANK-NICOLSON
}

\author{
Linisius Caesar Kevin Sinopa, Evi Noviani, Setyo Wira Rizki
}

\begin{abstract}
INTISARI
Persamaan panas atau disebut juga sebagai persamaan difusi adalah persamaan diferensial parsial berjenis parabolik yang terbentuk karena adanya proses perpindahan panas. Dalam penelitian ini, model dari persamaan panas yang diterapkan ialah berdimensi satu, yaitu persamaan yang hanya memiliki satu variabel spasial. Metode beda hingga merupakan suatu metode yang dapat menyelesaikan permasalahan kasus seperti persamaan panas dimensi satu yang dalam penerapannya didasarkan pada pendekatan deret Taylor. Dengan demikian, penelitian ini bertujuan untuk mengetahui model dari persamaan panas berdimensi satu dan menganalisis solusi persamaan tersebut menggunakan pendekatan metode beda hingga Crank-Nicolson. Pertama-tama, memodelkan proses perpindahan panas di sebuah penampang batang ke dalam bentuk persamaan diferensial parsial. Setelah diperoleh model, selanjutnya mendiskritisasikan persamaan panas dimensi satu dengan menggunakan skema Crank-Nicolson berdasarkan turunan numerik. Hasil diskritisasi ini membentuk pola iterasi agar memperoleh suatu sistem persamaan linier. Kemudian sistem persamaan linier diselesaikan sehingga menghasilkan solusi yang berupa matriks. Model persamaan panas dimensi satu adalah $\frac{\partial u(x, t)}{\partial t}-K \frac{\partial^{2} u(x, t)}{\partial x^{2}}=0$. Solusi persamaan panas dimensi satu dengan menggunakan pendekatan metode beda hingga Crank-Nicolson dinyatakan dalam bentuk umum yakni $\overrightarrow{\boldsymbol{u}}^{\boldsymbol{n}+\mathbf{1}}=\mathbf{D}^{\mathbf{- 1}} \mathbf{E} \overrightarrow{\boldsymbol{u}}^{\boldsymbol{n}}$. Berdasarkan bentuk dari solusi tersebut, maka dilakukan simulasi menggunakan program Scilab. Hasil simulasi menunjukkan bahwa terjadi perubahan suhu yang dipengaruhi oleh waktu akibat adanya proses perpindahan panas. Selain itu, galat yang diperoleh relatif kecil bahkan mendekati nol sehingga sangat mendekati nilai sejatinya.
\end{abstract}

Kata Kunci: Pendekatan Deret Taylor, Persamaan Panas Dimensi Satu, Metode Beda Hingga, Skema Crank-Nicolson.

\section{PENDAHULUAN}

Perubahan suhu merupakan salah satu masalah yang sering dijumpai dalam kehidupan sehari-hari. Perubahan suhu pada objek disebabkan oleh perubahan energi internal objek tersebut karena terjadi perpindahan energi antara objek dan lingkungannya. Energi yang dipindahkan antara objek dan lingkungannya karena perbedaan suhu diantara keduanya dinamakan panas [1]. Perpindahan panas adalah proses transisi energi termal dari suhu panas ke suhu yang lebih dingin sedemikian rupa sehingga objek atau sistem dan lingkungan sekitarnya mencapai kesetimbangan termal. Perpindahan panas bisa terjadi melalui tiga cara yang berbeda yaitu konduksi, konveksi dan radiasi, dimana proses perpindahan panas itu sendiri dapat dimodelkan secara matematika ke dalam suatu bentuk persamaan panas.

Persamaan panas dapat diselesaikan baik secara analitik maupun numerik. Solusi analitik merupakan solusi kontinu sehingga solusi dari nilai variabel bebas dapat ditemukan, sangat akurat dan tepat. Sedangkan solusi numerik solusi dapat diperoleh pada poin-poin grid terpisah, aproksimasi dan kesalahan kuantitatif harus dikendalikan dengan baik untuk ketelitian [2]. Dengan kata lain solusi analitik adalah penyelesaian yang memenuhi persamaan semula secara eksak sedangkan numerik adalah penyelesaian yang berupa hampiran [3]. Namun pada kenyataannya, dalam beberapa masalah untuk mencari penyelesaian secara analitik merupakan hal yang cukup rumit. Selain itu, permasalahan yang timbul tidak semuanya dapat dilakukan secara analitik, sehingga diperlukan sebuah solusi 
numerik untuk menyelesaikan persamaan panas. Salah satu metode numerik untuk penyelesaian persamaan panas adalah metode beda hingga.

Livne dan Glasner [4] menyatakan bahwa metode beda hingga merupakan metode yang akurat. Umumnya proses penyelesaian metode ini adalah dengan mentransformasi persamaan panas yang kontinu ke bentuk beda hingga yang diskrit menggunakan deret Taylor. Menurut Ross [5], penurunan beda hingga dapat dilakukan dari kiri, kanan dan tengah yang dikenal dengan beda maju, beda mundur dan beda pusat. Secara garis besar metode beda hingga memiliki bermacam skema yaitu skema eksplisit, skema implisit dan skema Crank-Nicolson [6].

Skema Crank-Nicolson merupakan skema yang dikenal cukup baik dalam menyelesaikan suatu permasalahan persamaan panas. Skema Crank-Nicolson merupakan pengembangan dari skema eksplisit dan implisit, dimana kelebihan skema ini ialah nilai error yang sangat kecil dan mempunyai tingkat kestabilan yang lebih baik dibandingkan skema-skema lainnya.

\section{PERSAMAAN PANAS PADA PENAMPANG BATANG}

Persamaan panas dapat diformulasikan dengan merumuskan persamaan aliran panas. Aliran panas ini diilustrasikan seperti pada Gambar 1 berikut:

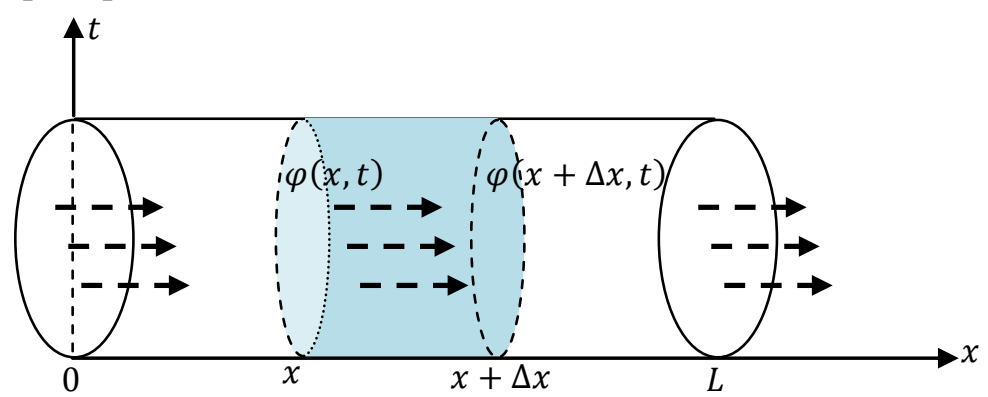

Gambar 1 Aliran Panas pada Penampang Batang

Terdapat beberapa asumsi yang perlu diperhatikan, diantaranya:

1. Aliran energi panas dalam penampang batang dari sisi yang lebih panas ke sisi yang lebih dingin.

2. Penampang batang berada di sepanjang sumbu $x$ positif dengan panjang $x=0$ menuju $x=L$.

3. Segmen dari ruas penampang batang berada di antara $x$ dan $x+\Delta x$ dimana $x<x+\Delta x$.

4. Permukaan samping dari penampang batang terisolasi sehingga aliran panas yang dimiliki tidak dapat keluar melalui permukaannya.

5. Luas dari penampang batang di kedua sisinya ialah sama yaitu $A$.

6. Suhu dari penampang batang dinyatakan sebagai bentuk fungsi $u$ yang bergantung pada setiap ruang $x$ dan setiap waktu $t$ yakni $u(x, t),(\forall x, t)$.

7. Tidak ada sumber energi panas lain $\left(E_{\text {sumber }}\right)$ yang dihasilkan di dalam penampang batang.

Diberikan kepadatan penampang batang, biasanya disebut massa jenis yang bernilai konstan yakni $\rho=\frac{m}{V}$ atau dapat ditulis $m=\rho * V$ dengan $m$ adalah massa dan $V$ adalah volume dari penampang batang.. Massa pada segmen penampang batang dari $x$ ke $x+\Delta x$ adalah $\rho * V=\rho * A * \Delta x$. Misalkan $c$ adalah konstanta panas yang menyatakan berapa banyaknya energi panas yang dibutuhkan saat menaikkan satuan unit suhu per-satuan unit massa penampang batang. Untuk menaikkan suhu pada segmen penampang batang dari $x$ ke $x+\Delta x$ sebesar satu derajat, dibutuhkan energi panas sebanyak $\rho * c * A * \Delta x$. Apabila suhunya ingin dinaikkan dari nol ke $u(x, t)$, maka energi panas yang dibutuhkan sebanyak $\rho * c * A * \Delta x * u(x, t)$. Total energi panas di sepanjang segmen penampang batang dari $x$ ke $x+\Delta x$ pada sebarang waktu $t$ adalah:

$$
E(t)=E_{[x, x+\Delta x]}(t)=\lim _{\Delta x \rightarrow 0} \sum_{x} \rho * c * A * \Delta x * u(x, t)
$$


atau diubah menjadi:

$$
E(t)=\int_{x}^{x+\Delta x} \rho * c * A * u(z, t) d z, t>0
$$

Untuk mendapatkan laju perubahan energi panas saat waktu $t$ di sepanjang segmen penampang batang dari $x$ ke $x+\Delta x$, maka Persamaan (1) diturunkan terhadap $t$ sehingga diperoleh:

$$
\frac{\partial E}{\partial t}=\int_{x}^{x+\Delta x} \rho * c * A * \frac{\partial u(z, t)}{\partial t} d z
$$

Selanjutnya misalkan $\varphi(x, t)$ adalah fungsi fluks panas dinyatakan sebagai banyaknya energi panas per-satuan unit luas yang mengalir melintasi penampang batang melintang di ruang $x$ saat waktu $t$ dengan menuju ke arah sumbu $x$ positif. Sesuai ilustrasi pada Gambar 1, maka fluks energi dapat ditulis:

$$
E_{\text {fluks }}=A \varphi(x, t)-A \varphi(x+\Delta x, t)
$$

Apabila digunakan hukum Newton tentang pendinginan yang dinyatakan sebagai:

$$
\varphi(x, t)=-k \frac{\partial u(x, t)}{\partial x}, k>0
$$

dimana konstanta $k$ yang disebut konduktivitas panas dari batang. Oleh karena itu, diperoleh persamaan untuk kecepatan aliran energi panas memasuki segmen penampang batang dari $x$ ke $x+\Delta x$, yaitu dengan mensubstitusi Persamaan (4) ke (3) yang menjadi:

sehingga didapatkan:

$$
E_{f l u k s}=k A \frac{\partial u(x+\Delta x, t)}{\partial x}-k A \frac{\partial u(x, t)}{\partial x}
$$

$$
E_{\text {fluks }}=\int_{x}^{x+\Delta x} \frac{\partial}{\partial x}\left(k A \frac{\partial u(z, t)}{\partial x}\right) d z
$$

Banyaknya energi panas dalam ruas segmen batang saat waktu $t$ dapat meningkat dengan dua cara: energi panas mengalir ke dalam segmen sampai ujung batang $\left(E_{f l u k s}\right)$ dan atau ada sumber energi panas lain dari dalam ruas segmen batang $\left(E_{\text {sumber }}\right)$, yang dirumuskan dengan kekekalan energi:

$$
\frac{\partial E}{\partial t}=E_{\text {fluks }}+E_{\text {sumber }}
$$

dengan asumsi bahwa tidak ada sumber energi panas lain yang dihasilkan di dalam batang, sehingga berdasarkan Persamaan (2) dan (5) maka Persamaan (6) menjadi:

$$
\begin{gathered}
\int_{x}^{x+\Delta x} \rho * c * A * \frac{\partial u(z, t)}{\partial t} d z=\int_{x}^{x+\Delta x} \frac{\partial}{\partial x}\left(k A \frac{\partial u(z, t)}{\partial x}\right) d z \\
\rho c \frac{\partial u(x, t)}{\partial t}-k \frac{\partial^{2} u(x, t)}{\partial x^{2}}=0 \\
\frac{\partial u(x, t)}{\partial t}-K \frac{\partial^{2} u(x, t)}{\partial x^{2}}=0
\end{gathered}
$$

dimana $K=\frac{k}{\rho c}$ merupakan koefisien difusi. Persamaan (7) disebut sebagai persamaan panas atau persamaan difusi yang berdimensi satu. Dalam menyelesaikan persamaan panas dimensi satu, diperlukan syarat tambahan yakni syarat awal dan syarat batas [7] berikut:

$$
\begin{gathered}
u(x, 0)=g(x)=x^{2}, 0 \leq x \leq \pi \\
u_{x}(0, t)=u_{x}(\pi, t)=0, t \geq 0
\end{gathered}
$$

serta solusi eksak yang berupa:

$$
u(x, t)=\frac{1}{3} \pi^{2}+\sum_{n=1}^{\infty} \frac{4(-1)^{n}}{n^{2}} \cos n x e^{-n^{2} K t}
$$




\section{DISKRITISASI INTERVAL PADA SUHU}

Diberikan suhu $u(x, t)$ dengan ruang $x$ dan waktu $t$ dibagi atau dipotong menjadi bagian-bagian kecil berhingga (disebut grid atau mesh). Dalam metode beda hingga, hal tersebut dinamakan sebagai diskritisasi. Banyaknya bagian-bagian grid ini terdapat di sepanjang interval yang telah ditentukan. Berikut akan digunakan interval sesuai pada Persamaan (8) yaitu $0 \leq x \leq \pi$ untuk ruang $x$ dan $0 \leq t \leq T$ untuk waktu $t$.

Apabila ruang $x$ pada interval $0 \leq x \leq \pi$ dibagi menjadi sejumlah titik-titik terpisahkan oleh selang ukur $\Delta x$ yang sama. Nilai tiap titiknya adalah:

atau secara umum ditulis:

$$
x_{0}=0, x_{1}=\Delta x, x_{2}=2 \Delta x, \ldots, x_{M}=\pi
$$

$$
x_{j}=j \Delta x, j=0,1,2, \ldots, M
$$

Jika dimisalkan $M$ adalah jumlah total dari selang ukur $\Delta x$ di ruang node (simpul) yang membagi $0 \leq x \leq \pi$, diperoleh:

$$
\Delta x=\frac{\pi}{M}
$$

Demikian pula apabila waktu $t$ pada interval $0 \leq t \leq T$ dibagi menjadi sejumlah titik-titik terpisahkan oleh selang ukur $\Delta t$ yang sama. Nilai tiap titiknya adalah:

atau secara umum ditulis:

$$
t_{0}=0, t_{1}=\Delta t, t_{2}=2 \Delta t, \ldots, t_{N}=T
$$

$$
t_{n}=n \Delta t, n=0,1,2, \ldots, N
$$

Jika dimisalkan $N$ adalah jumlah total dari selang ukur $\Delta t$ pada langkah waktu yang membagi $0 \leq t \leq T$, diperoleh:

$$
\Delta t=\frac{T}{N}
$$

Diskritisasi suhu $u(x, t)$ di sepanjang interval ruang $x$ dan waktu $t$ dapat dilihat pada Gambar 2 berikut:

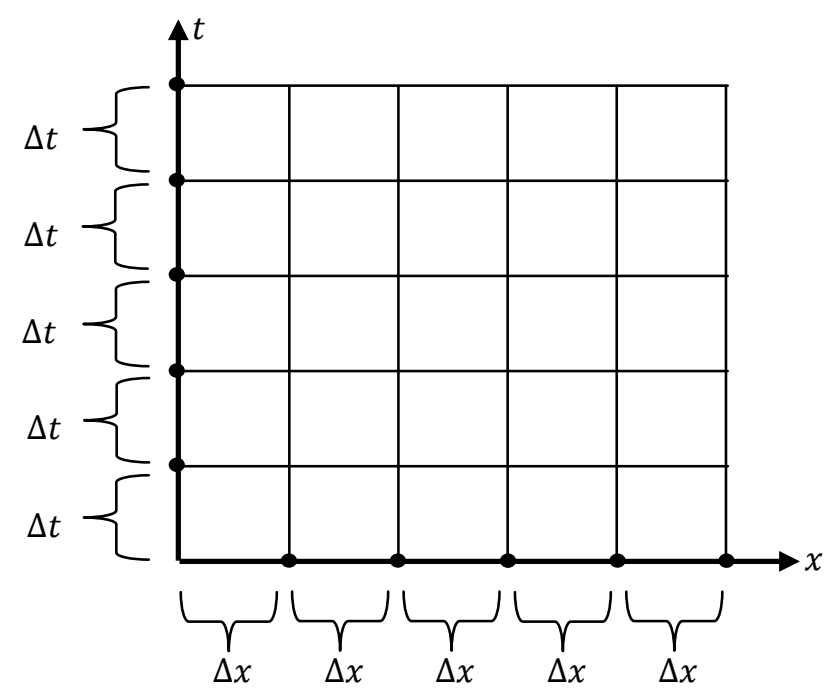

Gambar 2 Diskritisasi Selang Ruang dan Waktu

Berdasarkan Persamaan (10) dan (11), suhu $u(x, t)$ dapat dinyatakan $u\left(x_{j}, t_{n}\right)$ dimana nilai tiap titiknya di antara $0 \leq x \leq \pi$ dan $0 \leq t \leq T$. Untuk penyederhanaan penulisan, maka $u\left(x_{j}, t_{n}\right)$ dinotasikan sebagai:

$$
u\left(x_{j}, t_{n}\right)=u_{j}^{n}
$$




\section{PENDEKATAN DERET TAYLOR UNTUK METODE BEDA HINGGA}

Deret Taylor merupakan dasar untuk menyelesaikan masalah dalam metode numerik, terutama penyelesaian persamaan diferensial. Deret Taylor mempunyai suku sebanyak tak terhingga yang dalam praktiknya sulit memperhitungkan semua suku tersebut dan biasanya hanya diperhitungkan beberapa suku saja dengan mengabaikan sisanya [8]. Pandang deret Taylor sebagai nilai $f$ pada titik $x_{i+1}$ di sekitar titik $x_{i}$ yang dipotong sampai suku orde ke- $n$, yakni:

$$
f\left(x_{i+1}\right)=f\left(x_{i}\right)+f^{\prime}\left(x_{i}\right) \frac{\Delta x}{1 !}+f^{\prime \prime}\left(x_{i}\right) \frac{\Delta x^{2}}{2 !}+f^{\prime \prime \prime}\left(x_{i}\right) \frac{\Delta x^{3}}{3 !}+\cdots+f^{n}\left(x_{i}\right) \frac{\Delta x^{n}}{n !}+R_{n}
$$

dimana terdapat kesalahan pemotongan $R_{n}$ (disebut galat) berupa:

$$
R_{n}=f^{n+1}\left(x_{i}\right) \frac{\Delta x^{n+1}}{(n+1) !}+f^{n+2}\left(x_{i}\right) \frac{\Delta x^{n+2}}{(n+2) !}+\cdots
$$

Turunan numerik digunakan untuk memperkirakan bentuk yang diferensial kontinu menjadi bentuk diskrit [8]. Turunan numerik ini dibentuk berdasarkan penggunaan deret Taylor sehingga memperoleh suatu formula dari turunan numerik untuk tiga hampiran yaitu hampiran beda maju, hampiran beda mundur serta hampiran beda pusat yang dapat dituliskan pada Tabel 1 berikut:

Tabel 1 Formula Turunan Numerik

\begin{tabular}{|c|c|c|}
\hline Turunan Parsial & Hampiran Turunan Numerik & Tipe dan Orde \\
\hline$\frac{\partial f}{\partial x}=f^{\prime}\left(x_{i}\right)$ & $\frac{f\left(x_{i+1}\right)-f\left(x_{i}\right)}{\Delta x}$ & Beda maju orde satu \\
\hline$\frac{\partial f}{\partial x}=f^{\prime}\left(x_{i}\right)$ & $\frac{f\left(x_{i}\right)-f\left(x_{i-1}\right)}{\Delta x}$ & Beda mundur orde satu \\
\hline$\frac{\partial f}{\partial x}=f^{\prime}\left(x_{i}\right)$ & $\frac{f\left(x_{i+1}\right)-f\left(x_{i-1}\right)}{2 \Delta x}$ & Beda pusat orde satu \\
\hline$\frac{\partial^{2} f}{\partial x^{2}}=f^{\prime \prime}\left(x_{i}\right)$ & $\frac{f\left(x_{i+1}\right)-2 f\left(x_{i}\right)+f\left(x_{i-1}\right)}{\Delta x^{2}}$ & Beda pusat orde dua \\
\hline
\end{tabular}

Berdasarkan formula-formula yang ada di Tabel 1, apabila dipandang deret Taylor $u(x, t)$ di sekitar titik-titik yang telah ditentukan, maka didapatkan suatu formula pendekatan metode beda hingga pada Tabel 2 yang dituliskan dengan notasi Persamaan (12) berikut:

Tabel 2 Formula Pendekatan Metode Beda Hingga

\begin{tabular}{|c|c|c|}
\hline Turunan Parsial & Hampiran Beda Hingga & Tipe dan Orde \\
\hline$\frac{\partial u(x, t)}{\partial t}=\left.u_{t}\right|_{j} ^{n}$ & $\frac{u_{j}^{n+1}-u_{j}^{n}}{\Delta t}$ & $\begin{array}{c}\text { Beda maju orde satu } \\
\text { terhadap } t\end{array}$ \\
\hline$\frac{\partial u(x, t)}{\partial t}=\left.u_{t}\right|_{j} ^{n+1}$ & $\frac{u_{j}^{n+1}-u_{j}^{n}}{\Delta t}$ & $\begin{array}{c}\text { Beda mundur orde satu } \\
\text { terhadap } t\end{array}$ \\
\hline$\frac{\partial u(x, t)}{\partial x}=\left.u_{x}\right|_{j} ^{n}$ & $\frac{u_{j+1}^{n}-u_{j-1}^{n}}{2 \Delta x}$ & $\begin{array}{c}\text { Beda pusat orde satu } \\
\text { terhadap } x\end{array}$ \\
\hline$\frac{\partial u(x, t)}{\partial x}=\left.u_{x}\right|_{j} ^{n+1}$ & $\frac{u_{j+1}^{n+1}-u_{j-1}^{n+1}}{2 \Delta x}$ & $\begin{array}{c}\text { Beda pusat orde satu } \\
\text { terhadap } x\end{array}$ \\
\hline$\frac{\partial^{2} u(x, t)}{\partial x^{2}}=\left.u_{x x}\right|_{j} ^{n}$ & $\frac{u_{j-1}^{n}-2 u_{j}^{n}+u_{j+1}^{n}}{\Delta x^{2}}$ & $\begin{array}{c}\text { Beda pusat orde dua } \\
\text { terhadap } x\end{array}$ \\
\hline$\frac{\partial^{2} u(x, t)}{\partial x^{2}}=\left.u_{x x}\right|_{j} ^{n+1}$ & $\frac{u_{j-1}^{n+1}-2 u_{j}^{n+1}+u_{j+1}^{n+1}}{\Delta x^{2}}$ & $\begin{array}{c}\text { Beda pusat orde dua } \\
\text { terhadap } x\end{array}$ \\
\hline
\end{tabular}

Formula-formula di Tabel 2 ini nantinya digunakan untuk memperoleh skema Crank-Nicolson sekaligus syarat batas yang berupa Neumann. 


\section{SKEMA CRANK-NICOLSON PERSAMAAN PANAS DIMENSI SATU}

Skema Crank-Nicolson merupakan pengembangan dari skema eksplisit dan implisit yang dianggap sebagai nilai rata-rata variabel saat waktu $n$ dan waktu $n+1$. Skema Crank-Nicolson ini dapat diilustrasikan pada Gambar 3 berikut:

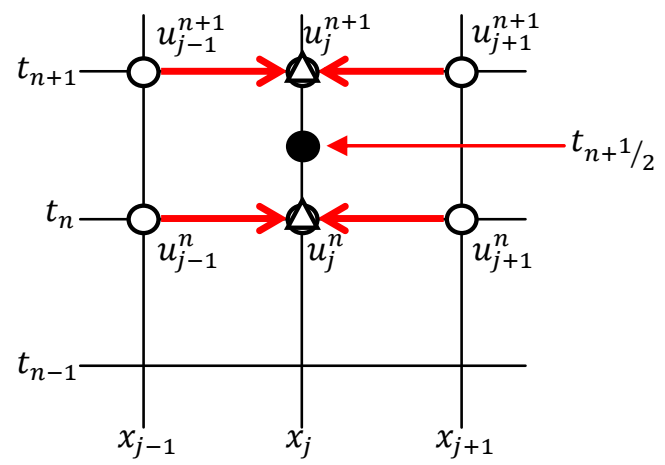

\section{Gambar 3 Skema Crank-Nicolson}

Mengacu formula pada Tabel 2, maka diterapkan hampiran beda maju dan beda mundur terhadap $u_{t}$ di titik $\operatorname{grid}\left(j, n+\frac{1}{2}\right)$ sehingga didapatkan nilai rata-rata, yakni:

$$
\left.u_{t}\right|_{j} ^{n+\frac{1}{2}}=\frac{1}{2}\left(\frac{u_{j}^{n+1}-u_{j}^{n+\frac{1}{2}}}{\frac{1}{2} \Delta t}+\frac{u_{j}^{n+\frac{1}{2}}-u_{j}^{n}}{\frac{1}{2} \Delta t}\right)
$$

yang disederhanakan menjadi:

$$
\left.u_{t}\right|_{j} ^{n+\frac{1}{2}}=\frac{u_{j}^{n+1}-u_{j}^{n}}{\Delta t}
$$

Kemudian diterapkan hampiran beda pusat terhadap $u_{x x}$ di titik grid $\left(j, n+\frac{1}{2}\right)$ sehingga didapatkan nilai rata-rata, yakni:

$$
\begin{gathered}
\left.u_{x x}\right|_{j} ^{n+\frac{1}{2}}=\frac{1}{2}\left(\left.u_{x x}\right|_{j} ^{n+1}+\left.u_{x x}\right|_{j} ^{n}\right) \\
\left.u_{x x}\right|_{j} ^{n+\frac{1}{2}}=\frac{1}{2}\left(\frac{u_{j-1}^{n+1}-2 u_{j}^{n+1}+u_{j+1}^{n+1}}{\Delta x^{2}}+\frac{u_{j-1}^{n}-2 u_{j}^{n}+u_{j+1}^{n}}{\Delta x^{2}}\right)
\end{gathered}
$$

Berdasarkan nilai rata-rata dari Persamaan (13) dan (14), maka Persamaan (7) yang merupakan persamaan panas dimensi satu selanjutnya diubah dengan mensubstitusikan skema Crank-Nicolson, sehingga memperoleh:

$$
\frac{u_{j}^{n+1}-u_{j}^{n}}{\Delta t}-K\left(\frac{u_{j-1}^{n+1}-2 u_{j}^{n+1}+u_{j+1}^{n+1}}{2 \Delta x^{2}}+\frac{u_{j-1}^{n}-2 u_{j}^{n}+u_{j+1}^{n}}{2 \Delta x^{2}}\right)=0
$$

Setelah itu, untuk semua variabel dengan superskrip $n$ pada Persamaan (15) dikelompokkan ke ruas kanan:

$$
\begin{aligned}
-\left[\frac{K}{2 \Delta x^{2}}\right] u_{j-1}^{n+1} & +\left[\frac{1}{\Delta t}+\frac{K}{\Delta x^{2}}\right] u_{j}^{n+1}-\left[\frac{K}{2 \Delta x^{2}}\right] u_{j+1}^{n+1} \\
& =\left[\frac{K}{2 \Delta x^{2}}\right] u_{j-1}^{n}+\left[\frac{1}{\Delta t}-\frac{K}{\Delta x^{2}}\right] u_{j}^{n}+\left[\frac{K}{2 \Delta x^{2}}\right] u_{j+1}^{n}
\end{aligned}
$$

Apabila diasumsikan sebagai berikut:

$$
A=\frac{K}{2 \Delta x^{2}} \quad B=\frac{1}{\Delta t}+\frac{K}{\Delta x^{2}} \quad C=\frac{1}{\Delta t}-\frac{K}{\Delta x^{2}}
$$

Maka, Persamaan (16) dapat disederhanakan menjadi:

$$
-A u_{j-1}^{n+1}+B u_{j}^{n+1}-A u_{j+1}^{n+1}=A u_{j-1}^{n}+C u_{j}^{n}+A u_{j+1}^{n}
$$


untuk $n=0,1, \ldots, N-1$ dan $j=0,1, \ldots, M$ dimana $M$ adalah banyaknya iterasi. Dengan memerlukan suatu pola iterasi, Persamaan (17) ini dibentuk sedemikian sehingga memperoleh sistem persamaan linier, yaitu:

$$
\begin{array}{ll}
j=0 & -A u_{-1}^{n+1}+B u_{0}^{n+1}-A u_{1}^{n+1}=A u_{-1}^{n}+C u_{0}^{n}+A u_{1}^{n} \\
j=1 & -A u_{0}^{n+1}+B u_{1}^{n+1}-A u_{2}^{n+1}=A u_{0}^{n}+C u_{1}^{n}+A u_{2}^{n} \\
j=2 & -A u_{1}^{n+1}+B u_{2}^{n+1}-A u_{3}^{n+1}=A u_{1}^{n}+C u_{2}^{n}+A u_{3}^{n} \\
\quad \vdots & \vdots \\
j=M-1 & -A u_{M-2}^{n+1}+B u_{M-1}^{n+1}-A u_{M}^{n+1}=A u_{M-2}^{n}+C u_{M-1}^{n}+A u_{M}^{n} \\
j=M & -A u_{M-1}^{n+1}+B u_{M}^{n+1}-A u_{M+1}^{n+1}=A u_{M-1}^{n}+C u_{M}^{n}+A u_{M+1}^{n}
\end{array}
$$

Selanjutnya, sistem persamaan linier pada Persamaan (18) akan diterapkan syarat tambahan yaitu syarat awal dan syarat batas yang digunakan untuk sekeliling daerah tinjauan suatu sistem persamaan linier dalam memberikan solusi. Oleh sebab itu, mengacu pada Persamaan (8) yang sudah diketahui sebelumnya, persamaan tersebut dapat ditulis ke dalam bentuk diskritisasi menjadi:

$$
\begin{gathered}
u_{j}^{0}=u(x, 0)=g(x)=g\left(x_{j}\right)=\left(x_{j}\right)^{2}, j=0,1, \ldots, M \\
\left.u_{x}\right|_{0} ^{n+\frac{1}{2}}=u_{x}(0, t)=0 \text { dan }\left.u_{x}\right|_{M} ^{n+\frac{1}{2}}=u_{x}(\pi, t)=0
\end{gathered}
$$

Berdasarkan syarat batas yang dimiliki berupa kondisi Neumann dengan didasarkan pada turunan parsial pertama $u_{x}$ di titik $\operatorname{grid}\left(j, n+\frac{1}{2}\right)$ untuk $j=0$ dan $j=M$, maka perlu adanya suatu hampiran beda pusat orde satu terhadap $u_{x}$ di titik grid $(j, n)$ dan $(j, n+1)$ yang terdapat pada Tabel 2 untuk mendefinisikan syarat batas tersebut. Karena itu, pandang kembali Gambar 3 sebagai ilustrasi skema Crank-Nicolson. Diketahui $u_{x}$ di titik grid $\left(j, n+\frac{1}{2}\right)$ yang terletak antara $u_{x}$ pada titik grid $(j, n)$ dan $(j, n+1)$, sehingga akan diperoleh nilai rata-ratanya, yakni:

$$
\begin{gathered}
\left.u_{x}\right|_{j} ^{n+\frac{1}{2}}=\frac{1}{2}\left(\left.u_{x}\right|_{j} ^{n+1}+\left.u_{x}\right|_{j} ^{n}\right) \\
\left.u_{x}\right|_{j} ^{n+\frac{1}{2}}=\frac{1}{2}\left(\frac{u_{j+1}^{n+1}-u_{j-1}^{n+1}}{2 \Delta x}+\frac{u_{j+1}^{n}-u_{j-1}^{n}}{2 \Delta x}\right) \\
\left.u_{x}\right|_{j} ^{n+\frac{1}{2}}=\frac{1}{2}\left(\frac{u_{j+1}^{n+1}-u_{j-1}^{n+1}+u_{j+1}^{n}-u_{j-1}^{n}}{2 \Delta x}\right)
\end{gathered}
$$

atau dapat ditulis:

$$
\left.u_{x}\right|_{j} ^{n+\frac{1}{2}}=\frac{u_{j+1}^{n+1}-u_{j-1}^{n+1}+u_{j+1}^{n}-u_{j-1}^{n}}{4 \Delta x}
$$

Persamaan (20) ini nantinya digunakan dalam hal penerapan syarat batas yang dimiliki pada Persamaan (19). Oleh karena itu, untuk syarat batas bawah $u_{x}$ di titik grid $\left(0, n+\frac{1}{2}\right)$, didefinisikan Persamaan (20) menjadi berikut:

$$
\begin{gathered}
\left.u_{x}\right|_{0} ^{n+\frac{1}{2}}=\frac{u_{0+1}^{n+1}-u_{0-1}^{n+1}+u_{0+1}^{n}-u_{0-1}^{n}}{4 \Delta x}=0 \\
u_{1}^{n+1}+u_{1}^{n}-u_{-1}^{n+1}-u_{-1}^{n}=0 \\
u_{-1}^{n+1}+u_{-1}^{n}=u_{1}^{n+1}+u_{1}^{n}
\end{gathered}
$$

Begitu juga untuk syarat batas atas $u_{x}$ di titik grid $\left(M, n+\frac{1}{2}\right)$, didefinisikan Persamaan (20) menjadi berikut:

$$
\begin{gathered}
\left.u_{x}\right|_{M} ^{n+\frac{1}{2}}=\frac{u_{M+1}^{n+1}-u_{M-1}^{n+1}+u_{M+1}^{n}-u_{M-1}^{n}}{4 \Delta x}=0 \\
u_{M+1}^{n+1}+u_{M+1}^{n}-u_{M-1}^{n+1}-u_{M-1}^{n}=0 \\
u_{M+1}^{n+1}+u_{M+1}^{n}=u_{M-1}^{n+1}+u_{M-1}^{n}
\end{gathered}
$$


Apabila sistem persamaan linier pada Persamaan (18) untuk $j=0$ dan $j=M$ diubah dengan mensubstitusikan Persamaan (21) dan (22), maka diperoleh:

$$
\begin{array}{lrl}
j=0 & B u_{0}^{n+1}-2 A u_{1}^{n+1} & =C u_{0}^{n}+2 A u_{1}^{n} \\
j=1 & -A u_{0}^{n+1}+B u_{1}^{n+1}-A u_{2}^{n+1} & =A u_{0}^{n}+C u_{1}^{n}+A u_{2}^{n} \\
j=2 & -A u_{1}^{n+1}+B u_{2}^{n+1}-A u_{3}^{n+1} & =A u_{1}^{n}+C u_{2}^{n}+A u_{3}^{n} \\
& \vdots & \vdots \\
j=M-1 & -A u_{M-2}^{n+1}+B u_{M-1}^{n+1}-A u_{M}^{n+1} & =A u_{M-2}^{n}+C u_{M-1}^{n}+A u_{M}^{n} \\
j=M & -2 A u_{M-1}^{n+1}+B u_{M}^{n+1} & =2 A u_{M-1}^{n}+C u_{M}^{n}
\end{array}
$$

Dari Persamaan (23) yang merupakan sistem persamaan linier tersebut, akan terbentuk secara umum suatu matriks tridiagonal sebagai berikut:

$$
\left[\begin{array}{ccccccc}
B & -2 A & 0 & \cdots & 0 & 0 & 0 \\
-A & B & -A & \cdots & 0 & 0 & 0 \\
0 & -A & B & \cdots & 0 & 0 & 0 \\
\vdots & \vdots & \vdots & \ddots & \vdots & \vdots & \vdots \\
0 & 0 & 0 & \cdots & -A & B & -A \\
0 & 0 & 0 & \cdots & 0 & -2 A & B
\end{array}\right]\left[\begin{array}{c}
u_{0}^{n+1} \\
u_{1}^{n+1} \\
u_{2}^{n+1} \\
\vdots \\
u_{M-1}^{n+1} \\
u_{M}^{n+1}
\end{array}\right]=\left[\begin{array}{ccccccc}
C & 2 A & 0 & \cdots & 0 & 0 & 0 \\
A & C & A & \cdots & 0 & 0 & 0 \\
0 & A & C & \cdots & 0 & 0 & 0 \\
\vdots & \vdots & \vdots & \ddots & \vdots & \vdots & \vdots \\
0 & 0 & 0 & \cdots & A & C & A \\
0 & 0 & 0 & \cdots & 0 & 2 A & C
\end{array}\right]\left[\begin{array}{c}
u_{0}^{n} \\
u_{1}^{n} \\
u_{2}^{n} \\
\vdots \\
u_{M-1}^{n} \\
u_{M}^{n}
\end{array}\right]
$$

Persamaan (24) ini dapat dinyatakan dalam bentuk $\mathbf{D} \overrightarrow{\boldsymbol{u}}^{\boldsymbol{n}+\boldsymbol{1}}=\mathbf{E} \overrightarrow{\boldsymbol{u}}^{\boldsymbol{n}}$ dimana $\mathbf{D}$ dan $\mathbf{E}$ adalah matriks tridiagonal. Karena unsur-unsur di $\overrightarrow{\boldsymbol{u}}^{\boldsymbol{n}}$ sudah diketahui berdasarkan syarat awal dan syarat batas, untuk itu matriks D dipindahkan ke ruas kanan. Dengan demikian, unsur-unsur di $\overrightarrow{\boldsymbol{u}}^{\boldsymbol{n}+\boldsymbol{1}}$ akan dicari penyelesaiannya yaitu $\overrightarrow{\boldsymbol{u}}^{\boldsymbol{n}+\mathbf{1}}=\mathbf{D}^{\mathbf{- 1}} \mathbf{E} \overrightarrow{\boldsymbol{u}}^{\boldsymbol{n}}$, sehingga Persamaan (24) disajikan kembali dalam bentuk:

$$
\left[\begin{array}{c}
u_{0}^{n+1} \\
u_{1}^{n+1} \\
u_{2}^{n+1} \\
\vdots \\
u_{M-1}^{n+1} \\
u_{M}^{n+1}
\end{array}\right]=\left[\begin{array}{ccccccc}
B & -2 A & 0 & \cdots & 0 & 0 & 0 \\
-A & B & -A & \cdots & 0 & 0 & 0 \\
0 & -A & B & \cdots & 0 & 0 & 0 \\
\vdots & \vdots & \vdots & \ddots & \vdots & \vdots & \vdots \\
0 & 0 & 0 & \cdots & -A & B & -A \\
0 & 0 & 0 & \cdots & 0 & -2 A & B
\end{array}\right]^{-1}\left[\begin{array}{ccccccc}
C & 2 A & 0 & \cdots & 0 & 0 & 0 \\
A & C & A & \cdots & 0 & 0 & 0 \\
0 & A & C & \cdots & 0 & 0 & 0 \\
\vdots & \vdots & \vdots & \ddots & \vdots & \vdots & \vdots \\
0 & 0 & 0 & \cdots & A & C & A \\
0 & 0 & 0 & \cdots & 0 & 2 A & C
\end{array}\right]
$$

untuk $n=0,1, \ldots, N-1$ dan $j=0,1, \ldots, M$ dengan $M$ adalah banyaknya iterasi.

\section{SIMULASI SCILAB DISERTAI INTERPRETASI HASIL}

Agar lebih memahami proses dari metode ini, maka ditunjukkan simulasi menggunakan program Scilab untuk penyelesaian numerik skema Crank-Nicolson pada persamaan panas berdimensi satu, yang kemudian dilakukan perbandingan dengan solusi eksaknya untuk memperoleh suatu nilai error (disebut galat).

Penyelesaian skema Crank-Nicolson persamaan panas dimensi satu jika diterapkan Persamaan (25) yang sudah diketahui sebelumnya, maka diperoleh solusi numerik berupa $\overrightarrow{\boldsymbol{u}}^{\boldsymbol{n}+\mathbf{1}}$ untuk $n=0,1, \ldots, 49$ dan $j=0,1, \ldots, 50$, yakni dinyatakan dalam Tabel 3 berikut:

Tabel 3 Nilai Solusi Numerik $\overrightarrow{\boldsymbol{u}}^{n+1}$

\begin{tabular}{|c|c|c|c|c|c|c|}
\hline $\overrightarrow{\boldsymbol{u}}^{\mathbf{0}}$ & $\overrightarrow{\boldsymbol{u}}^{\mathbf{1}}$ & $\overrightarrow{\boldsymbol{u}}^{\mathbf{2}}$ & $\cdots$ & $\overrightarrow{\boldsymbol{u}}^{\mathbf{4 8}}$ & $\overrightarrow{\boldsymbol{u}}^{\mathbf{4 9}}$ & $\overrightarrow{\boldsymbol{u}}^{\mathbf{5 0}}$ \\
\hline 0 & 0,0160000 & 0,0320000 & $\cdots$ & 0,7670480 & 0,7828871 & 0,7987064 \\
\hline 0,0039478 & 0,0199478 & 0,0359478 & $\cdots$ & 0,7709585 & 0,7867929 & 0,8026071 \\
\hline 0,0157914 & 0,0317914 & 0,0477914 & $\cdots$ & 0,7826878 & 0,7985079 & 0,8143066 \\
\hline$\vdots$ & $\vdots$ & $\vdots$ & $\ddots$ & $\vdots$ & $\vdots$ & $\vdots$ \\
\hline 9,0958274 & 9,0067556 & 8,8149882 & $\cdots$ & 6,2176281 & 6,1885344 & 6,1598899 \\
\hline 9,4787681 & 9,2212921 & 8,9398471 & $\cdots$ & 6,2396218 & 6,2101819 & 6,1812016 \\
\hline 9,8696044 & 9,1738144 & 9,0489453 & $\cdots$ & 6,2469724 & 6,2174166 & 6,1883237 \\
\hline
\end{tabular}


Apabila nilai solusi numerik di Tabel 3 dilakukan perbandingan dengan solusi eksak menggunakan Persamaan (9), diperoleh suatu galat yang ditulis pada Tabel 4 berikut:

Tabel 4 Perbandingan Hasil Solusi Eksak dan Crank-Nicolson

\begin{tabular}{|c|c|c|c|c|}
\hline $\boldsymbol{t}$ & $\boldsymbol{x}$ & Eksak & Numerik (Crank-Nicolson) & Galat \\
\hline \multirow{4}{*}{0} & 0 & 0,0000020 & 0 & $2,00 \mathrm{E}-06$ \\
\cline { 2 - 5 } & 25 & 2,4674031 & 2,4674011 & $2,00 \mathrm{E}-06$ \\
\cline { 2 - 5 } & 50 & 9,8656064 & 9,8696044 & $4,00 \mathrm{E}-05$ \\
\hline \multirow{4}{*}{25} & 0 & 0,3999990 & 0,3999985 & $5,00 \mathrm{E}-07$ \\
\cline { 2 - 5 } & 25 & 2,8506469 & 2,8504487 & $1,98 \mathrm{E}-06$ \\
\cline { 2 - 5 } & 50 & 7,0989426 & 7,1027020 & $3,76 \mathrm{E}-03$ \\
\hline \multirow{4}{*}{50} & 0 & 0,7987488 & 0,7987064 & $4,24 \mathrm{E}-05$ \\
\cline { 2 - 5 } & 25 & 3,0883869 & 3,0883935 & $6,60 \mathrm{E}-06$ \\
\cline { 2 - 5 } & 50 & 6,1856114 & 6,1883237 & $2,71 \mathrm{E}-03$ \\
\hline
\end{tabular}

Tabel 4 merupakan perbandingan antara solusi eksak (sejati) dan solusi numerik skema CrankNicolson. Adapun beberapa iterasi yang digunakan dalam hal perbandingan ini yaitu 0, 25 dan 50 . Hasil perbandingan menunjukkan bahwa terdapat selisih sangat kecil yang bahkan mendekati nol antara kedua solusi tersebut. Karena galat yang diperoleh relatif kecil, dengan demikian nilai dari solusi numerik pada Tabel 3 dikatakan sebagai solusi hampiran yang sangat mendekati nilai sejatinya.

Selanjutnya sesuai dengan solusi numerik berupa $\overrightarrow{\boldsymbol{u}}^{\boldsymbol{n}+\mathbf{1}}$ yang ada di Tabel 3, maka dapat diilustrasikan suatu grafik seperti pada Gambar 4 berikut:

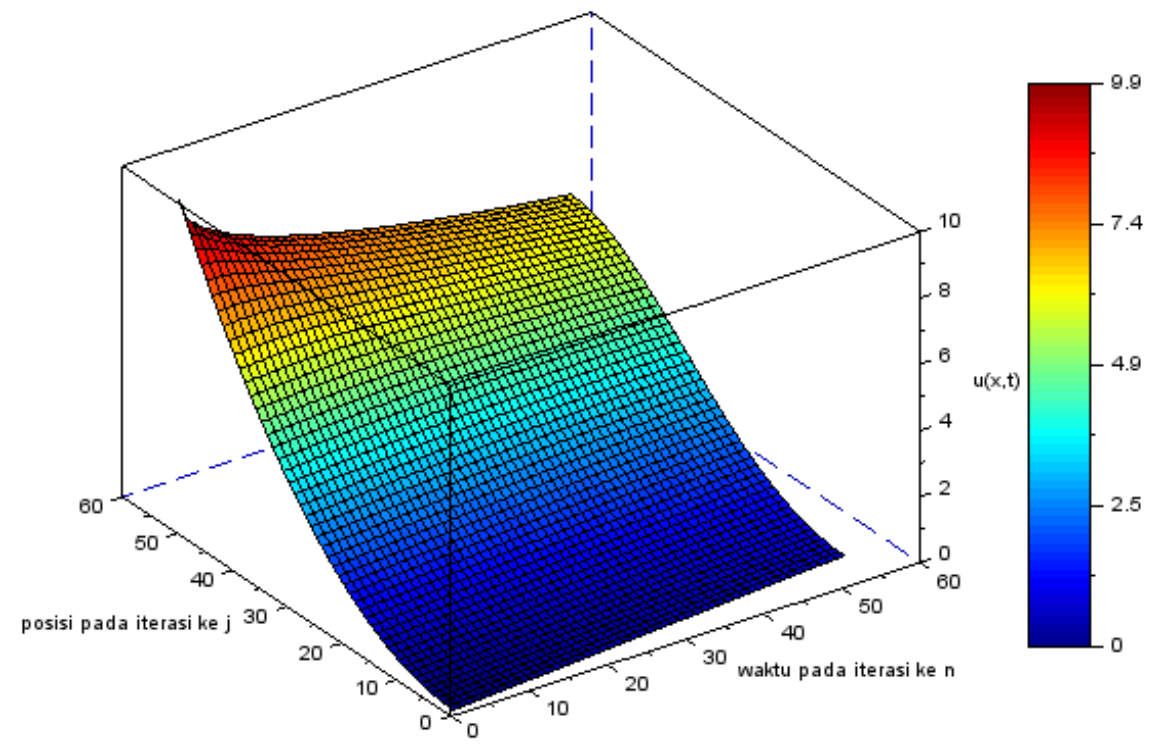

\section{Gambar 4 Grafik Solusi Numerik dari Persamaan Panas Dimensi Satu untuk Skema Crank-Nicolson}

Gambar 4 merupakan grafik hasil solusi dari persamaan panas dimensi satu menggunakan pendekatan metode beda hingga Crank-Nicolson. Perlu diketahui bahwa warna merah pada Gambar 4 ialah suhu yang sangat panas, sedangkan warna biru suhu yang sangat dingin. Pada simulasi ini, suhu mengalami perubahan warna secara signifikan. Hal tersebut dipengaruhi oleh waktu dari iterasi $t_{0}$ yang terus berjalan sampai iterasi yang ditentukan yakni $t_{50}$, sehingga mengubah posisi di titik-titik $x$. Semakin lama waktu yang terus berjalan, maka semakin terjadinya perubahan warna yang semula. Artinya dapat dikatakan bahwa suhu mengalami penyebaran ke seluruh benda atau lingkungan di sekitarnya hingga mencapai suhu kesetimbangan. 


\section{KESIMPULAN}

Model dari persamaan panas dimensi satu adalah $\frac{\partial u(x, t)}{\partial t}-K \frac{\partial^{2} u(x, t)}{\partial x^{2}}=0$. Selain itu, solusi untuk persamaan panas dimensi satu dengan menggunakan pendekatan metode beda hingga Crank-Nicolson diperoleh dalam bentuk rumus yang berupa $\overrightarrow{\boldsymbol{u}}^{\boldsymbol{n + 1}}=\mathbf{D}^{\mathbf{- 1}} \mathbf{E} \overrightarrow{\boldsymbol{u}}^{\boldsymbol{n}}$. Hasil simulasi menunjukkan bahwa terjadi perubahan suhu yang dipengaruhi oleh waktu akibat adanya proses perpindahan panas. Kemudian galat yang diperoleh relatif kecil bahkan mendekati nol sehingga sangat mendekati nilai sejatinya.

\section{DAFTAR PUSTAKA}

[1] Halliday, David; Resnick, Robert dan Walker, Jearl. Fisika Dasar Edisi 7 Jilid 2. Jakarta: Erlangga; 2010.

[2] Lam, Chung Yau. Applied Numerical Methods for Partial Differential Equation. Singapore: Prentice-Hall. Inc; 1994.

[3] Susila, I Nyoman. Dasar-Dasar Metode Numerik. Bandung: FMIPA ITB; 1993.

[4] Livne, E. \& Glasner, A. A Finite Difference Scheme for the Heat Conduction Equation. Journal of Computational Physics. Volume 58, pp. 59-66; 1985.

[5] Ross, Shepley L. Differential Equations. Third Edition. New Edition. New York: John Willey \& Sons. Inc; 1984.

[6] Sulpiani, Ririn dan Widowati. Solusi Numerik Persamaan Difusi dengan Menggunakan Metode Beda Hingga. Jurnal Sains dan Matematika. Volume 21, pp. 68-74; 2013.

[7] Shen, Shujun dan Liu, F. Error Analysis of an Explicit Finite Difference Approximation for the Space Fractional Diffusion Equation with Insulated Ends. The ANZIAM Journal. Volume 46 (E), pp. 871-887; 2005.

[8] Triatmodjo, Bambang. Metode Numerik Dilengkapi dengan Program Komputer. Yogyakarta: Beta Offset; 2002.

LINISIUS CAESAR KEVIN SINOPA : Jurusan Matematika FMIPA UNTAN, Pontianak kevin.linisius@gmail.com

EVI NOVIANI

: Jurusan Matematika FMIPA UNTAN, Pontianak evi_noviani@math.untan.ac.id

SETYO WIRA RIZKI

: Jurusan Matematika FMIPA UNTAN, Pontianak setyo.wirarizki@math.untan.ac.id 